\title{
Memperkuat 'Urf dalam Pengembangan Hukum Islam
}

\author{
Ach. Maimun \\ (Institut Keagamaan Islam Annuqayah, Jl. PP.Annuqayah Guluk Guluk, Kabupaten \\ Sumenep 69463, Email: mymoon221@gmail.com)
}

\begin{abstract}
Abstrak:
Sejauh ini, keberadaan 'urf sebagai sumber hukum Islam tidak menonjol. Padahal ‘urf memiliki posisi penting untuk pengembangan Islam di Nusantara yang kaya budaya. 'Urf dapat menjadi pembendung kolompok yang anti terhadap tradisi lokal. Para ulama sejatinya telah berbicara panjang lebar tentang 'urf sebagai dasar hukum. Para mujtahid dan mufti disyaratkan menguasai tradisi suatu masyarakat dan cermat mempertimbangkannya. Untuk itu diperlukan upaya penguatan 'urf dalam rangka pengembangan hukum Islam agar dapat tetap berperan di masa depan. Tujuan itu dapat dilakukan dengan beberapa langkah, yaitu memperbaiki cara memahami dan mendudukkan nash sebagai landasan utama hukum Islam, menegaskan posisi fiqih sebagai hasil ijtihad manusiawi yang historis dan kultural, dan melakukan negosiasi antara doktrin Islam dengan tradisi sekaligus menciptakan tradisi baru sebagai wujud penerjemahan doktrin yang bersifat mutlak.
\end{abstract}

Kata-kata Kunci:

Urf , Tradisi Lokal, Hukum Islam, syariah

\begin{abstract}
:
The existence of 'urf as one of sources of Islamic law is not dominant while it has an important position in the context of Islamic development in Indonesia, which is rich of culture and tradition. 'Urf can be a barrier against those who are anti-local traditions. Actually, Islamic scholars have discussed a lot about 'urf as the legal basis in the context of Islamic law. Mujtahid (experts in islamic law) and mufti (advisers on religious law) are required to be knowledgable of the traditions of a society and carefully consider them.Therefore, it is necessary to strengthen the 'urf for developing Islamic law in order to keep it playing a role in the future. In so doing, it is necessary to take several steps; improving the way to understand and place the texts of the Quran as the main foundation of Islamic law, affirming the
\end{abstract}


position of Islamic jurisprudence as the result of historical and cultural human interpretation and judgement (ijtihad), and negotiating between Islamic doctrine and tradition while creating new traditions as a form of absolute doctrinal translation.

\section{Key Words:}

Urf, Local Tradition, Islamic Law, Sharia

\section{Pendahuluan}

Menurut Ibnu Khaldûn (1332-1406 M) selain empat dasar fiqih (al-Qur'an, Sunnah, ijma' dan qiyas), dasar-dasar yang lain tidak terlalu prinsip. Sumber-sumber tersebut-seperti istihsân, istishâb, istislâh dan 'urf-sebatas sumber tambahan dan levelnya yang tidak signifikan (dhu'f al-madârik) serta tidak banyak dibicarakan (syudzîz al-qaul fihô). ${ }^{1}$ Karena alasan itu, ia tidak berbicara tentang 'urf dan dasar-dasar yang lain ketika berbicara singkat tentang disiplin ushul fiqih dalam Muqaddimah-nya.

Walaupun demikian, urf yang biasa disebut "tradisi" hakikatnya sangat penting dalam penetapan hukum Islam. Bahkan alQarafi mengharuskan para mujtahid untuk mengenal tradisi suatu masyarakat lebih dahulu sebelum memberikan fatwa sehingga dapat menjawab persoalan yang dihadapi dan tidak berseberangan dengan kemaslahatan umat. ${ }^{2}$ Arti penting 'urf salah satunya dapat dilihat dari apresiasi Islam atas tradisi yang telah ada pada masyarakat Arab sejak sebelum kedatangannya. Islam lahir di tengah suatu budaya dan sistem nilai, bahkan di tengah kepercayaan dan praktek keagamaan yang telah semarak. Semua itu justru menjadi miliu dan dan memberikan "konteks" bagi kelahiran Islam. ${ }^{3}$

\footnotetext{
${ }^{1}$ Abd al-Rahmân Ibnu Khaldûn, Muqaddimah li Kitâb al-'Ibar wa Dîwân al-Mubtadâ wa al-Khabar fi Ayyâm al-'Arab wa al-'Ajam wa al-Barbar wa Man 'Âsharahum min Dzawi alShulthân al-Akbar, Vo. 1, (Beirut: Dâr al-Kutub al-'Ilmiyyah, 1992), 484.

2Lihat Syihâb al-Dîn al-Qarafî, Anwâr al-Burûq fî̀ Anwấ' al-Furûq, Vol 3, (Kairo: Dar alKutub al-'Arabiyyah, 1344 H), III49.

${ }^{3}$ Lihat F.E. Peters, Mohammad and the Origin of Islam, (New York: State University of New York State, 1995), 105. Lihat juga Joseph Henninger, "Pre-Islamic Bedouin Religion," dalam Marlyn L. Swartz (ed. \& trans.) Studies on Islam, (New York: Oxford University Press, 1981), 15. Bahkan Watt berkesimpulan bahwa Nabi Muhammad mendapatkan pengetahuan tentang konsep-konsep Biblikal secara umum dari
} 
Arti penting 'urf semakin terasa ketika Islam memasuki dunia non-Arab. Islam yang "terbungkus" budaya Arab berhadapan dengan budaya dan tradisi yang berbeda. Tidak jarang, para tokoh agama justru gagap melihat keragaman budaya dan tradisi luar sehingga cenderung menganggapnya sebagai "sesat" dan tidak islami. Yang muncul kemudian adalah anggapan bahwa Islam yang benar dan murni adalah "Islam yang bercorak Arab". Jika muncul Islam bercorak non-Arab yang apresiatif atas tradisi lokal maka ia dianggap "Islam sinkretik" yang tidak murni dan menyimpang atau "Islam pinggiran”. Arti penting 'urf ini semakin menguat dengan munculnya gerakan Islam yang cenderung kearab-araban, menggunakan nash secara tekstual, bahkan memaksakan nash keluar konteksnya sehingga hukum Islam menjadi kaku, stagnan dan tidak mampu mengikuti keragaman budaya dan perkembangan zaman.

Dalam konteks fiqih, pemahaman positif atas suatu tradisi yang berbeda menjadi penting agar fiqih tetap bisa membumi dalam kehidupan masyarakat. Dalam hal ini sebenarnya fiqih melalui ushûl al-figh-nya telah menyediakan kerangka epistemologi dengan menjadikan 'urf sebagai salah satu sumber hukum. Hanya saja, 'urf sering diabaikan dan dikalahkan oleh makna harfiah teks yang menjadi pusat rujukan penetapan hukum. Berikut akan dilihat apa dan bagaimana urf itu sebenarnya berikut potensinya pengembangan hukum Islam yang humanis.

\section{'Urf: Teori dan Variannya}

Terdapat banyak definisi tentang 'urf dalam berbagai buku Ushul Fiqih, walaupun intinya senada. Antara lain, menurut Ahmad Fahmi Abu Sunnah, bahwa 'urf adalah peristiwa yang berulang-ulang yang tidak disebabkan oleh keniscayaan rasional. ${ }^{4}$ Sedang menurut Wahbah al-Zuhayli, 'urf adalah sesuatu yang dibiasakan oleh sekelompok orang baik berupa tindakan ('amali) atau ungkapan

lingkungan intelektualnya di Mekkah. Lihat Montgomery Watt, Muhammad, Prophet and Statesman, (New York: Oxford University Press, 1961), 41.

${ }^{4}$ Ahmad Fahmi Abû Sunnah, Al-'Urf wa al-'Âdah fi Ra'y al-Fuqahâ', (Mesir: Dâr al-Fikr al-'Arabî, t.t., hlm. 8. Wahbah al-Zuhaylî juga mengutip definisi ini yang menurutnya bersumber dari Syarh al-Tahrîr. Lihat Wahbah al-Zuhaylî, Ushûl al-Figh al-Islâmî, (Damaskus: Dâr al-Fikr, 1986), II: 828. 
(qaulî) yang memiliki makna khusus. ${ }^{5}$ Senada dengan itu, Abd alWahhab Khallaf mendefinisikan 'urf dengan sesuatu yang dikenal oleh masyarakat dan berlangsung dalam kehidupannya, baik berupa ungkapan, perbuatan atau tindakan meninggalkan sesuatu. ${ }^{6}$

Dari berbagai definisi tersebut, 'urf terdiri dari beberapa unsur: (a) berupa kebiasaan, (b) dikenal dan berlaku di kalangan masyarakat, (c) berupa tindakan atau ungkapan, (d) bukan berdasar keniscayaan rasional yang mesti terjadi, karena ia sekedar kebiasaan ('adah). Walaupun ada yang membedakan 'urf dengan 'âdat -yang sama-sama bisa diartikan kebiasaan-tapi para ulama secara umum tidak membedakannya.7 Namun tetap penting dicatat bahwa 'urf pada dasarnya lebih spesifik dari 'âdat. Karena 'urf merupakan kebiasaan yang berlaku umum dan tidak alamiah karena bersumber dari perenungan dan pengalaman. Sedang 'âdat adalah semua jenis kebiasaan, baik berlaku umum atau bagi orang atau kasus tertentu seperti kebiasaan pribadi serta juga meliputi sesuatu yang alamiah seperti terbit dan terbenamnya matahari. ${ }^{8}$ Maka dalam beberapa kasus, 'âdat juga bisa menjadi dasar hukum.

Secara umum, ragam 'urf dapat dilihat dari tiga sisi: 9 Pertama, dari sisi bentuknya, 'urf terbagi dua: (a) Lafdzî (ungkapan), suatu ungkapan yang bermakna tertentu tetapi telah dikenal masyarakat luas, seperti kata "daging" yang tidak mencakup daging ikan. Jika ada orang bersumpah tidak akan makan daging, maka ia boleh saja makan ikan. (b) Fi'lî (tindakan), suatu tindakan yang mendapat pengakuan secara sosial dari masyarakat luas seperti bentuk jual beli mu'athâth, jual beli langsung serah terima tanpa akad secara verbal.

Kedua, dari sisi cakupannya 'urf terbagi dua: (a) 'âm (umum), kebiasaan yang berlaku pada masyarakat sangat luas, seperti mengangguk sebagai jawaban positif, dan (b) khâsh (khusus) hanya

5Wahbah al-Zuhaylî, Ushûl al-Figh..., 828.

${ }^{6}$ Abd al-Wahhab Khallaf, 'Ilm al-Ushûl al-Fiqh, (Kairo: Dâr al-Qalam, 1978), 89.

7Pandangan ini bisa dilihat dalam Abd al-Wahhab Khallaf, Ibid.

8Lihat Mushthafâ Zarqa', Al-Madkhal 'ala al-Figh al-'Âm, Vol. 3, (Beirut: Dâr al-Fikr, 1968), 840; Abd al-Azîz al-Khayyâth, Nadzariyyat al-`Urf, (Amman: Maktab al-Aqshâ, t.t.), 24 .

${ }^{9}$ Fahmi Abu Sunnah, Al-'Urf..., 16; Mushthafa Zarqa', Al-Madkhal..., 844; AlKhayyath, Nadzhariyyat..., 26 
meliputi masyarakat tertentu saja, seperti tradisi ruwatan di kalangan masyarakat muslim Yogyakarta. ${ }^{10}$

Ketiga, dari sisi keabsahannya terbagi dua: (a) shahîh (dibenarkan), yakni yang tidak berseberangan dengan nash, tidak menghilangkan kemaslahatan dan mendatangkan kemudaratan, seperti menabur bunga di kuburan sebagai ungkapan bela sungkawa dan penghormatan atas yang meninggal. (b) Fâsid (tidak bisa dibenarkan), yang sebaliknya, seperti bisnis prostitusi dan praktek seks bebas.

\section{Otoritas dan Kontroversi 'Urf sebagai Dasar Hukum}

Para ulama yang menjadikan 'urf sebagai dasar hukum mendasarkan pada dalil hadits Ibnu Mas'ûd: Mâ ra'âhu al-muslimûn hasan fa huwa 'inda Allâh hasan, wa mâ ra'âhu al-muslimûn sayyi'â fa huwa 'inda Allâh sayyi' (Apa yang dianggap baik oleh orang Islam, maka ia baik menurut Allah, dan apa yang dianggap jelek oleh orang Islam, maka ia jelek menurut Allah). ${ }^{11}$ Para ulama juga menegaskannya dengan kaidah Al-tsâbit bi al-'urf ka al-tsâbit bi al-nash (yang ditetapkan dengan 'urf sama dengan yang ditetapkan berdasar nash).

'Urf yang disepakati dapat diterima sebagai dasar hukum adalah 'urf shahîh. Yang paling mendasar adalah bahwa apapun 'urf yang berlaku di tengah suatu masyarakat, selama tidak berseberangan dengan nash dapat menjadi dasar hukum. Artinya ia tetap bisa diberlakukan, bahkan pada pemegang otoritas harus tetap menjaga dan menjadikannya sebagai pedoman dalam keputusan hukum.12 Dengan menjadikan 'urf, sebagai salah satu dasar, hukumhukum yang ditetapkan akan terus mengalami perkembangan sesuai perkembangan kehidupan, seperti dikatakan Ibnul Qayyim Taghayyur al-fatâwâ wa ikhtilâfuhâ bi hasb taghayyur al-azminah wa al-amkinah wa al-

10Muhammad Roy Purwanto, "Akulturasi Islam dan Budaya Jawa pada Tradisi Ruwatan di Kalangan Muslim Yogyakarta," Istiqro' (Jurnal Penelitian Islam Indonesia), Volume 07, Nomor 01, 2008, 35-57.

11Menurut al-Zaila'î, seperti dikutip Wahbah al-Zuhaylî, hadits tersebut adalah hadits gharîb-marfü'. Tapi sejauh pengamatannya, hadits tersebut hanya ungkapan Ibnu Mas'ûd (mauqûfî) (Nashb al-Râyah, IV/133). Hadits tersebut diriwayatkan oleh Ahmad, al-Bazzâr dan al-Thabrâni dari Ibnu Mas'ûd, dan para periwayatnya dapat dipercaya penuh (dalam Majma' al-Zawấ'id, juz I/178). Lihat Wahbah al-Zuhaylî, Ushûl..., juz II: 830 .

${ }^{12}$ Abd al-Wahhab Khallaf, 'Ilm al-Ushûl..., 89. 
ahwâl wa al-niyyât wa al-'awấ'id (Perubahan dan perbedaan fatwa disebabkan oleh perubahan waktu, tempat, kondisi, niat dan kebiasaan).

Tapi secara lebih detail, 'urf sebagai kebiasaan yang bisa menjadi dasar hukum adalah sebuah kebiasaan yang terjadi dalam mayoritas kasus dan oleh mayoritas suatu masyarakat, mulai dari kelompok masyarakat yang kecil hingga masyarakat dunia. Di sini keberlakuannya sesuai dengan cakupan ruang dan waktunya. Karena itu muncul kaidah Taghayyur al-ahkâm bi taghayyur al-amkinah wal azminah (hukum bisa berubah dengan perubahan tempat dan waktu). Selain itu, kebiasaan tersebut harus telah berlangsung lama pada saat akan menjadikannya sebagai dasar hukum. Maka muncul kaidah $\mathrm{La}$ 'ibrat li al-'urf al-thârî ('Urf yang baru muncul tidak bisa dijadikan dasar bagi kasus yang telah lama). ${ }^{13}$

Pada uraian detailnya terjadi perbedaan pendapat, terutama dalam konteks tarik menarik antara 'urf dan nash pada saat keduanya tampak tidak sejalan. Garis besar perbedaan pandangan para ulamasebagai pemetaan awal-dapat disimpulkan sebagai berikut: ${ }^{14}$

\begin{tabular}{|c|c|c|c|c|}
\hline No & URF & $\begin{array}{l}\text { DALIL } \\
\text { LAWAN }\end{array}$ & KEBERLAKUAN & PENGANUT \\
\hline 01 & 'Urf & Nash khâsh & Nash khâs berlaku & Ittifâq \\
\hline 02. & 'Urflafdzî & Nash'âm & $\begin{array}{l}\text { Takhshîsh atas nash } \\
\text { 'âm dengan 'urf }\end{array}$ & Ittifâq \\
\hline 03. & 'Urf'amalî̀ & Nash 'âm & $\begin{array}{l}\text { Takhshîsh atas nash } \\
\text { 'âm dengan 'urf }\end{array}$ & $\underline{\text { Hanafiyah }}$ \\
\hline 04. & 'Urf'amalî & Nash 'âm & $\begin{array}{l}\text { 'Urf tidak berlaku, } \\
\text { yang berlaku nash }\end{array}$ & Al-Qarafi \\
\hline 05. & $\begin{array}{l}\text { 'Urf yang } \\
\text { muncul } \\
\text { sesudah Nash }\end{array}$ & Nash 'âm & 'Urf tidak berlaku & Ittifâq \\
\hline 06. & $\begin{array}{l}\text { 'Urf sebagai } \\
\text { 'Illat }\end{array}$ & Nash & $\begin{array}{l}\text { Nash tergantung } \\
\text { 'illat. }\end{array}$ & Jumhûr \\
\hline 07. & 'Urf & $\begin{array}{l}\text { Qiyâs } \\
\text { (Tidak } \\
\text { nash) }\end{array}$ & $\begin{array}{l}\text { 'Urf yang berlaku } \\
\text { atas dasar istihsân }\end{array}$ & $\begin{array}{l}\text { Hanafiyah } \\
\text { dan } \\
\text { Malikiyah }\end{array}$ \\
\hline
\end{tabular}

${ }^{13}$ Abd al-Azîz al-Khayyâth, Nadzariyyah..., 52-57.

${ }^{14}$ Dimodifikasi dari beberapa sumber, antara lain al-Zarqa', Al-Madkhal..., 900 dan alZuhaylî, Ushûl..., 833 


\begin{tabular}{|l|l|l|l|l|}
\hline 08. 'Urf & 'Urf didahulukan & Malikiyah \\
\hline 09. & 'Urf & $\begin{array}{l}\text { Maslahah } \\
\text { mursalah } \\
\text { mursalahah } \\
\text { qiyas }\end{array}$ & $\begin{array}{l}\text { Padan prinsipnya } \\
\text { 'urf didahulukan, } \\
\text { tapi dalam } \\
\text { penerapannya ada } \\
\text { beberapa } \\
\text { perbedaan dengan } \\
\text { Hanafiyah dan } \\
\text { Malikiyah }\end{array}$ & $\begin{array}{l}\text { Syafi'iyah } \\
\text { dan }\end{array}$ \\
Hanabilah \\
\hline 10. & 'Urf & Istihsân & $\begin{array}{l}\text { Memakai 'urf } \\
\text { karena tidak } \\
\text { menerima istihsân }\end{array}$ & $\begin{array}{l}\text { Syafi'iyah } \\
\text { dan } \\
\text { Hanabilah }\end{array}$ \\
\hline
\end{tabular}

Kesimpulan umumnya adalah bahwa berbagai kemungkinan perubahan hukum dengan mempertimbangkan 'urf adalah hukumhukum yang didasarkan pada ijtihad, seperti melalui qiyâs, istihsân, dan maslahah mursalah berikut dalil-dalil dhannî. Sedang yang didasarkan pada dalil qath'î tetap berlaku universal melintasi batas ruang dan waktu. Seluruh ulama madzhab sepakat atas hal ini.

\section{Signifikansi 'Urf dalam Bentuk Tradisi Lokal}

Pengakuan atas 'urf sebagai salah satu dasar hukum berarti juga menunjukkan tidak adanya maksud membangun masyarakat yang sama sekali baru dalam segala aspeknya. Hukum Islam masih mengakui "kontinuitas" dengan masa lalu di satu sisi dan "perubahan" serta "pengembangan" di sisi lain dalam aspek hukum, adat istiadat, sistem nilai dan pola hidup, baik Arab atau wilayahwilayah lainnya.

Sejarah membuktikan adanya dialektika Islam dengan tradisi sebelumnya yang sangat beragam. Apresiasi tersebut secara umum dapat dibagi menjadi empat kategori:15 (1) apresiasi negatif, berupa penolakan atas segala bentuk tradisi yang dianggap menyimpang secara prinsip, seperti praktik transaksi berbunga; (2) apresiasi

15Khalîl Abd al-Karîm dalam Al-Judzûl al-Târikhiyyah al-Syarî'ah al-Islâmiyyah, membagi apresiasi Islam atas tradisi Arab menjadi tiga: (1) mengambil sebagian dan menolak sebagian (2) mengambil setengah-setengah dengan disertai modifikasi, (3) mengambil secara utuh. Lihat Khalil Abdul Karim, Historisitas Syari'ah Islam, Terj. M. Faisol Fatawi, (Yogyakarta: Pustaka Alief, 2003), 12. 
duplikatif, berupa penerimaan secara utuh atas tradisi atau ajaran sebelumnya seperti adopsi hukum rajam dari Yahudi, (3) apresiasi modifikatif, dengan mengambil tradisi dengan disertai modifikasi seperti tradisi poligami; (4) apresiasi purifikatif, penerimaan tradisi yang disertai pemurnian karena dinilai mengandung unsur menyimpang seperti ibadah haji.

Pengakuan atas 'urf-berupa tradisi lokal-dalam sejarah hukum Islam tampak pada penerimaan atas tradisi Arab, Yahudi dan Nasrani. Berbagai tradisi diakomodir secara kreatif dan menjadi bagian integral hukum Islam. Itu juga terlihat pada sikap para ulama dalam ijtihadnya. Imam Malik menjadikan 'amal ahl al-madinah yang merupakan 'urf sebagai dasara hukum, Imam Syafi'ie memiliki qaul qadîm dan qaul jadîd karena-salah satunya-perbedaan 'urf dalam ruang dan waktu yang berbeda.

Dengan demikian, gagasan tentang Islam kaffah, universal dan tidak mentolerir tradisi lokal disertai dikotomi Islam "tradisi besar" (great tradition) dan "tradisi kecil" (little tradition) tidak produktif, apalagi anggapan bahwa Islam non-Arab sebagai "Islam pinggiran" dan "Islam sinkretik". ${ }^{16}$ Gagasan yang semarak dan hadir dalam bentuk gerakan radikal yang mengusung "Islam otentik" di segala ruang dan waktu sama sekali mengingkari 'urf sebagai salah satu sumber hukum yang diakui para mujtahid sejak era al-salaf al-shâlih.

Pengingkaran terhadap 'urf dengan islamisasi yang lebih bercorak arabisasi dalam bentuk penyeragaman dalam segala aspeknya sulit dibenarkan dengan pertimbangan antara lain: (1) bertentangan dengan prinsip al-Qur'an dan hadits yang mentolerir perbedaan dan mengakui tradisi lokal, (2) berseberangan dengan sunnatullah bahwa menjadikan satu umat di seluruh dunia adalah mustahil (Q.S. 16: 93), dan (3) tidak sejalan dengan "sunnah" para ulama sejak awal Islam. Hal itu diperparah oleh keyakinan bahwa Islam yang dianut adalah satu-satunya bentuk Islam yang benar dan yang lain salah. Padahal tanpa disadari, Islam yang dibawa ke kawasan lain tidak jarang bercorak budaya Arab yang mengidap

\footnotetext{
16Aswab Mahasin, "Masyarakat Madani dan Lawan-Lawannya: Sebuah Mukadimah” (Kata Pengantar) dalam Ernest Gellner, Membangun Masyarakat Sipil Prasyarat Menuju Kebebasan, Mizan, Bandung, 1995, hlm. XI. Bandingkan dengan Talal Asad, The Idea of an Anthropologi of Islam, (Washington: Georgetown University, 1986), 21-22.
} 
lokalitas dan historisitas. ${ }^{17}$ Karena itu, gerakan tersebut sejatinya hendak memaksakan universalisasi kultur lokal tertentu (Arab) ke seluruh penjuru dunia.

Keterbukaan Islam yang diwujudkan melalui 'urf dalam hukum Islam menjadi bagian dari epistemologi hukum Islam, karena bagaimanapun nash tetaplah terbatas dan tidak merinci segala hal. Ditambah dengan kehidupan yang terus berkembang dan melahirkan tradisi berikut persoalan baru. ${ }^{18}$ Sementara di sisi lain 'urf sangat terkait dengan kemaslahatan suatu masyarakat yang memiliki 'urf tersebut. Tetap memberlakukan 'urf merupakan bagian dari upaya memelihara maslahah. Karena salah satu bentuk kemaslahatan adalah tidak merombak tradisi positif yang telah berlaku dan akrab di tengah masyarakat dari generasi ke generasi. ${ }^{19}$ Keterbukaan atas perbedaan dan perubahan dengan 'urf ini justru menguatkan teori adaptabilitas hukum Islam seperti dianut kaum reformis semacam Suhbi Mahmashani dan peneliti Barat semisal Linant de Bellefonds. ${ }^{20}$

Memang tidak semua 'urf dapat dipertahankan dan itu diakui oleh para ulama dari dulu sampai kini. Tapi ia tetap merupakan potensi epistemologis yang menjanjikan karena, di samping nash tidak menjelaskan rincian segala hal dan memelihara 'urf adalah bagian dari perwujudan kemaslahatan, ia juga dapat memfungsikan nash dengan lebih baik, ketika (1) 'urf menjadi 'illat dari suatu nash sehingga ketika 'urf itu berubah, hukum juga berubah dan nash tidak

\footnotetext{
17Itu terlihat dari penampilan sehari-hari yang sering menggunakan simbol-simbol Arab baik dalam cara berpakaian atau aksesorisnya dan disertai pemahaman tekstual terhadap pesan Kitab Suci yang sering hanya berobjek bicara masyarakat Arab dalam kultur 15 abad lalu.

18Jargon para ulama tentang ini al-nushûsh mutanâhiyah wa al-waqấ'i' ghair mutanâhiyah (teks itu terbatas sedang realitas tidak terbatas). Al-Syahrastanî, Al-Milal wa al-Nihal, Vol. 1, (Kairo: Musthafâ Bâb al-Halabî, 1967), 199.

${ }^{19}$ Yûsuf al-Qaradlâwi, Madkhal li Dirâsah al-Syarî'ah al-Islâmiyyah, (Kairo: Maktabah Wahbah, 2001), 169.

${ }^{20}$ Teori ini berseberangan dengan teori kebadian hukum Islam yang menyatakan bahwa dalam konsepnya sesuai dengan perkembangan serta metodologinya, hukum Islam adalah abadi dan karenanya tidak dapat diadaptasikan dengan perubahan sosial. Penganut teori ini antara lain C. S. Horgronje dan J. Schacht serta para ahli hukum muslim tradisionalis. Lihat M. Khalid Masood, islamic Legal Philosophy, A. Study of Abu Ishaq al-Shatibi's Life and Thought, (Delhi: International Islamic Publisher, 1989), 1-2.
} 
berlaku; (2) dapat menjadi takhshîsh atas nash 'âm sehingga bisa saja berseberangan dengan nash. ${ }^{21}$

Dengan demikian, 'urf meniscayakan pemahaman yang tidak harfiah atas nash. Pemahaman yang diperlukan harus menyentuh maqâshid al-syarî'ah. Maka 'urf yang diakui-walaupun berseberangan dengan makna harfiah nash tapi tidak berseberangan dengan maqâshid al-syarî'ah-diyakini dapat mewujudkan kemaslahatan dan menghindari kemudaratan. Karena itu hukum Islam akan lebih fleksibel dan dapat menyentuh persoalan yang lebih luas.

Dengan itu diharapkan eksistensi hukum Islam yang tidak hanya berfungsi sebagai "kontrol sosial", tapi juga "rekayasa sosial", dengan memahaminya secara lebih dalam.22 Melalui 'urf, umat Islam dapat: (1) memanfaat potensi tradisi lokal yang sangat kaya dan berakar kuat sebagai wujud "pribumisasi", (2) memasukkan nafas Islam ke dalam tradisi yang mengandung unsur penyimpangan sebagai wujud "negosiasi", serta (3) membuang tradisi yang secara prinsip berseberangan dengan prinsip ajaran Islam sebagai wujud "Islamisasi". Dengan demikian, upaya memasyarakatkan Islam dapat menghindari "konflik" antara ajaran dan tradisi lokal yang telah mapan yang justru sangat tidak menguntungkan. ${ }^{23}$

Penerapan 'urf sebagai salah satu sumber hukum memerlukan kesiapan para intelektual untuk: (1) terbuka atas perbedaan budaya dan memandangnya sebagai kekayaan yang harus dikelola dengan

\footnotetext{
21Seperti aturan transaksi (hadits) agar barang-barangnya jelas, sementara dalam masyarakat tertetu biasa terjadi penjualan buah di pohon yang belum jelas jumlahnya.

22M. A. Sahal Mahfudz, Fiqih Sosial: Upaya Pengembangan Madzhab Qauli dan Manhaji, pidato penerimaan Gelar Doktor Honoris Causa Bidang Fiqih Sosial, Universitas Islam Negeri (UIN) Syarif Hidayatullah Jakarta, 2003, 38-39.

${ }^{23}$ Empat pola tersebut (islamisasi, pribumisasi, negosiasi dan konflik) merupakan tipologi hubungan Islam dan budaya lokal. Joko Surjo dkk., Agama dan Perubahan Sosial; Studi Tentang Hubungan Antara Islam, Masyarakat dan Struktur Sosial-Politik Indonesia, Pusat Studi Antar Universitas-Studi Sosial UGM. Yogyakarta, 1993. Tipologi ini juga digunakan oleh Abdul Munir Mulkan dalam melihat hubungan antara Islam murni dan budaya lokal di Wuluhan. Lihat Abdul Munir Mulkhan, Islam Murni dan Masyarakat Petani, Bentang Budaya, Yogyakarta, 2000, hlm. 29-30. Lihat juga Abdul Munir Mulkhan, "Muhammadiyah dan Keragaman Budaya Lokal," dalam Zakiyuddin Baidhawy dan Mutohharun Jinan, Agama dan Pluralitas Budaya Lokal (Surakarta: Pusat Studi Budaya dan Perubahan Sosial Universitas Muhammadiyah Surakarta, 2003), 216.
} 
baik, (2) keterbukaan untuk tidak melihat model Islam lain sebagai Islam yang "sesat" dan "lumbung bid'ah", (3) untuk itu diperlukan pemahaman yang mementingkan prinsip syari'at daripada makna harfiahnya, sekaligus (4) menyadari bahwa hukum Islam yang hadir dalam kehidupan bukan sepenuhnya hukum Tuhan yang abadi dan universal, tapi juga tafsir manusia dalam lokalitas dan historisitasnya. Tradisi lokal adalah wujud penafsiran suatu masyarakat tertentu berdasar cara berpikir dan kepentingan tradisi tertentu.

\section{Strategi Pengembangan melalui ‘Urf}

Fiqih didefinisikan sebagai ilmu yang membahas hukumhukum syariat yang bersifat praktis yang didasarkan pada dalil-dalil berupa nash yang dianalisis secara detail. ${ }^{24}$ Karena itu, nash ditempatkan pada posisi yang dominan. Dominasi nash semakin menguat ketika kehidupan keagamaan semakin mengarah pada aspek formal. Kedudukan nash yang sedemikian penting ini tidak jarang disikapi secara tidak proporsional oleh sebagian pihak. Sikap tersebut muncul dalam bentuk: (1) pembacaan harfiah terhadap nash sehingga tidak jarang hukum Islam menjadi kaku, anti perubahan, dan resisten terhadap perkembangan budaya; (2) semangat pencarian dalil nash yang berlebihan sehingga tidak jarang menimbulkan "pemaksaan" terhadap dalil dan berakibat pada keluarnya nash dari makna dan konteksnya, (3) pengabaian pada konteks ketentuan dan hikmah atau maqâshid syarî'ah yang tidak selalu disebutkan secara verbal dalam nash sehingga hukum Islam terperangkap dalam hikmah yang semu atau bahkan menyimpang dari tujuan luhurnya.

Untuk ini, yang diperlukan adalah memposisikan nash secara proporsional di satu sisi dan menegaskan posisi 'urf di sisi lain dengan beberapa langkah. Pertama, memahami nash secara hati-hati sebagai sumber hukum dan bukan hukum itu sendiri. Karena nash tidak selalu jelas walaupun tampak mudah dipahami. Karena itu, para ulama membuat klasifikasi muthlaq-muqayyad, mujmal-mubayyan,

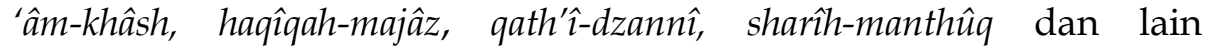
sebagainya. ${ }^{25}$ Masing-masing masih dibagi lagi menjadi sub-sub

\footnotetext{
24Subhî Mahmashanî, Falsafat al-Tasyrî’ fi al-Islâm, (Beirut: Dâr al-`Ilm li al-Malâyin, 196), 21.

25Muhammad Abû Zahrah, Ushûl al-Fiqh, (Beirut: Dâr al-Fikr al-'Arabî, t.t.), 115 dst.
} 
bahasan yang lebih detail. Kompleksitas itu juga terkait dengan konteksnya sehingga asbâb al-nuzĥul dan asbâb al-wurûd menjadi sesuatu yang niscaya dalam memahami nash.

Sikap tidak proporsional terhadap nash dapat menyebabkan hilangnya kehati-hatian dan berganti sikap terburu-buru dalam mengambil kesimpulan dengan mengabaikan kompleksitasnya. Sikap seperti ini dapat dilihat dalam banyak fatwa baik personal atau institusional. Tapi di sisi lain, sikap tidak proporsional itu muncul dari keterbatasan penguasaan atas ilmu-ilmu metodologis seperti ushul fiqih, ilmu tafsir, ilmu hadits, bahasa Arab, dan sejarah Islam. Keduanya sama-sama membuka ruang yang amat besar atas kesalahan penarikan kesimpulan dan penetapan makna nash atau pemaksaan atas nash untuk menjadi dasar dari hukum tertentu.

Kedua, memahami bahwa fiqih adalah hasil ijtihad para mujtahid yang bersifat manusiawi dan historis sedang syariah adalah ajaran yang ilahi dan transhistoris. Syariah terdiri dari aturan-aturan yang bersifat prinsip baik menyangkut aturan umum atau sebagian teknisnya. Dalam ajaran yang terkait dengan ritual ('ubîdiyah) banyak aturan yang diatur sampai detail dengan teknisnya oleh Alquran dan hadits. Di sini yang ditekankan adalah kepatuhan penghambaan ( $\left.t a a^{\prime} a b b u d \hat{\imath}\right)$ sehingga tidak sepenuhnya bisa dipahamai secara rasional (ghair ta'aqqulî). Sedang dalam ajaran yang terkait dengan kehidupan sosial (mu'âmalah ijtimâ'iyyah) umumnya bersifat prinsip umum tanpa ketentuan teknis dan bisa dipahami secara rasional ( $\left.t a^{\prime} a q q u l \hat{\imath}\right)$, karena terkait langsung dengan kemashlahatan kehidupan yang dijalani oleh manusia di dunia. ${ }^{26}$

Untuk uraian detail dan hal-hal yang memerlukan pembahasan, para ulama melakukan ijtihad. Sebagai usaha manusiawi, hasil ijtihad dalam bentuk hukum fiqih tidak selalu bertumpu pada nash, tapi juga mempertimbangkan hal-hal lain yang dikenal dengan mashâdir altasyrî' al-khârijiyyah (sumber penetapan hukum eksternal), salah satunya adalah 'urf. ${ }^{27}$ 'Urf merupakan unsur realitas historis di mana nash senantiasa berdialektika dengannya. Dalam konteks ini, peran sentral manusia yang menentukan dialektika antara nas dan tradisi. Karena nash itu tak bisa berdiri sendiri dalam membentuk kehidupan

\footnotetext{
26Subhî Mahmashanî, Falsafat al-Tasyrî’..., 199.
}

27Ibid.,198. 
manusia. Dengan demikian tradisi adalah kompatriot nash yang disandingkan oleh para ulama untuk membangun peradaban umat menjadi islami. 28

Secara teoritis, seorang mujtahid tidak hanya disyaratkan untuk mengetahui nash berikut perangkat metodologisnya, tapi ia juga mengetahui berbagai tradisi (ma'rifat' âdat al-nâs). Bahkan mufti juga patut memperhatikan tradisi yang telah berjalan dalam kehidupan masyarakat yang menjadi sasaran fatwa. Secara praktis, hukum Islam memberi ruang kepada 'urf sebagai dasar yang bersanding dengan nash. Karena itu, mengabaikan 'urf dengan hanya mendasarkan pada nash telah menyalahi teori dan praktik para ulama sejak zaman dulu kala.

Ketiga, menegaskan posisi urf yang secara normatif diakui oleh nash. Para mujtahid dipersyaratkan untuk mengetahui tradisi suatu masyarakat karena mereka tahu bahwa mempertimbangkan tradisi dalam bentuk 'urf memiliki landasan nash. Secara lebih tegas, ketika para mujtahid mendasarkan ijtihadnya berdasarkan 'urf bukan berarti mengabaikan nash, justeru ia sedang mendasarkan kepada nash karena nash sendiri yang menegaskan bahwa 'urf atau 'adat harus dipertimbangkan dan dapat menjadi dasar. Al-Sarakhsî menegaskan bahwa "yang tetap berdasar tradisi seperti yang tetap berdasar nash (al-tsâbit bi al-'urfka al-tsâbit bi al-nash).29

Tradisi terbentuk berdasar nalar publik yang sehat atau yang dikenal al-'urf al-shahîh (tradisi positif). Tradisi dapat berupa sesuatu yang telah nyaman dijalani oleh masyarakat, membuat kehidupan sosial berjalan lancar, mampu menggerakkan unsur-unsur sosial bahkan menjamin kehidupan duniawi mereka. Dengan fungsi itu, mengabaikan tradisi dapat mempersulit kehidupan masyarakat, membuat unsur-unsurnya tidak berjalan baik, merenggangkan kohesi sosial, dan akhirnya dapat menganggu dakwah dan pelaksanaan ajaran agama. Semua itu justeru berseberangan dengan prinsip syariah yang ditegaskan oleh Alquran mâ ja'ala Allâh 'alaikum fi al-dîn min haraj (Allah tidak menjadikan atas kalian kesulitan dalam agama).

\footnotetext{
${ }^{28 N a s r}$ Hâmid Abû Zayd, Mafhûm al-Nash, (Beirut: Al-Markaz al-Tsaqâfî al-'Arabî, 1996), 9.

${ }^{29}$ Muhammad Abû Zahrah, Ushûl al-Fiqh..., 73.
} 
Penegasan Ibn Mas'ûd, seorang sahabat terkemuka, bahwa segala yang dianggap baik oleh orang-orang Islam maka ia menurut Allah juga baik (mâ ra'âhu al-muslimûn hasan fa huwa 'inda Allâh hasan) ${ }^{30}$ merupakan salah satu landasan 'urf. Dengan ini pula, suatu tradisi yang sudah dipandang baik oleh orang Islam dapat menjadi dasar hukum tanpa harus memaksakan nash kalau memang tidak ada nash yang terkait langsung. Apa yang dikatakan Ibn Mas' ûd adalah kesimpulan mendalam dari apresiasi positif Islam atas tradisi dan sikap itu diajarkan berdasar nash. Bahkan Nabi Muhammad mendorong umat Islam untuk membuat tradisi baru melalui haditsnya man sanna fi al-islâm sunnat hasanat fa lah $\hat{u}$ ajruhâ wa ajru man 'amila bihâ ba'dahû (barang siapa yang merintis suatu tradisi baik dalam Islam, ia mendapat pahalanya dan pahala orang yang melakukannya sesudahnya). ${ }^{31}$

Dalam kaitannya dengan nash, 'urf tidak hanya dipilah dengan shahîh (baik) dan fâsid (buruk) atau memilah ajaran dengan 'ibâdah (ritual) dan mu'âmalah (sosial-transaksional), tapi juga ushîl (prinsip) dan furû' (uraian). Ushûl adalah prinsip ajaran yang terdiri dari aturan yang bersifat umum yang ditetapkan oleh nash. Termasuk di ranah ini adalah ajaran-ajaran yang bersifat mutlak (syarî'ah mutlaqah) baik berupa 'ibâdah atau mu'âmalah. Sedang fur $\hat{u}^{\prime}$ meliputi uraian dari prinsip yang meliputi aturan-aturan teknisnya yang juga meliputi 'ibâdah dan mu'âmalah. Ketetapan nash terhadap prinsip dan uraian teknisnya, tidak dapat dimodifikasi oleh tradisi. Namun jika nash hanya berbicara prinsipnya yang umum atau muthlaq, tradisi dapat ditawarkan untuk teknis operasionalnya, baik ritual atau sosial serta memberi ruang kreativitas dan upaya pengembangannya. Memperbanyak baca shalawat sebagai ashl, pelaksanaannya secara teknis sebagai furû' dapat memanfaatkan tradisi seperti melalui perkumpulan di waktu tertentu dan menetapkan jumlah tertentu. Karena ushul tidak menetapkan uraian teknis pelaksanaannya.

Dalam contoh lainnya, ketika nash tidak membicarakan secara langsung terkait hukum sesuatu, 'urf dapat menjadi pedoman

30Berdasar takhrîj para ulama, ia bukan hadits Nabi seperti diduga oleh tokoh-tokoh Hanafiyah, tapi ia adalah pernyataan 'Abd Allah ibn Mas'ûd. Lihat Subhî Mahmashanî, Falsafat al-Tasyrî’.., 241.

31Riwayat Muslim. Hadits ini dikutip oleh K.H. Muhammad Hasyim Asy'ari dalam Risâlah Ahl al-Sunnah wa al-Jamâ'ah, (Tebuireng: Maktabah al-Turats al-Islami, t.t.), 22. 
penetapannya dengan kembali pada prinsip umum syariah, salah satunya adalah kemaslahatan umat manusia (mashlah al-nâs). Karena itu tidak perlu memaksakan suatu nash untuk menjadi dalil tradisi yang tidak dijelaskan secara langsung oleh nash. Karena selama tidak ada larangan langsung atau berseberangan dengan prinsip syariah, segala hal adalah boleh. Memberikan sejumlah barang dalam lamaran (khithbah) adalah tradisi di daerah tertentu, sementara tidak ada nash yang memerintahkan atau melarangnya. Tradisi ini bisa dibenarkan untuk dilakukan bahkan dapat dianjurkan karena dinilai baik oleh masyarakat sesuai tradisi yang telah berjalan. Tradisi sebagai salah salah satu faktor determinan ikatan sosial, menjaganya adalah bagian dari menjaga stabilitas sosial yang dapat mengantar pada kemaslahatan yang menjadi tujuan akhir suatu ketetapan hukum. Stabilitas dan kemaslahatan sosial merupakan cita-cita ajaran Islam melalui hukum-hukum yang ditetapkannya. Dengan itu, urf tertentu memiliki orientasi dan peran yang searah dengan syariat Islam.

Keempat, negosiasi antara nash dengan tradisi. Strategi ini penting terutama terkait dengan tradisi yang dinilai menyimpang dari nash sehingga dapat disebut 'urf fâsid (kebiasaan yang jelek). Tradisi tidak bisa begitu saja dibuang atau diharamkan secara fiqih. Karena bisa jadi suatu tradisi yang dinilai menyimpang disebabkan oleh adanya unsur-unsur yang menyimpang yang bisa dipilah tanpa harus menafikan seluruh tradisi tersebut. Karapan sapi sebagai salah satu contohnya, dapat saja dikategorikan tradisi yang jelek sehingga bisa disimpulkan haram. Dalam menyikapi ini, perlu dipilah unsur apa yang membuatnya menjadi haram. Argumentasinya karena adanya penyiksaan terhadap binatang (sapi). Dalam strategi negosiasi, argumen ini bisa diterima tapi tidak berarti harus membuang tradisinya secara keseluruhan. Karena unsur yang membuatnya haram yaitu penyiksaan binatang dapat saja dibuang tanpa harus melenyapkan tradisi kerapan sapi. Dengan demikian, dapat terjadi kerapan sapi dalam bentuk lomba pacuan sapi tanpa penyiksaan terhadap binatang seperti lomba pacuan kuda atau binatang lainnya. Dalam hal ini tradisi dijaga dan hukum Islam ditegakkan. Hukum Islam tidak melenyapkan tradisi dan tradisi tidak melanggar hukum Islam.

Proses negosiasi antara agama dan tradisi juga terlihat dalam tradisi ruwatan di kalangan masyarakat Jawa yang pada mulanya 
terdiri dari ruwatan bumi yang dianggap sangar, ruwatan desa yang dianggap menyandang sukerto dan ruwatan gimbel dengan sesaji untuk anak bajang. Ritual tersebut ada yang dijaga dengan modifikasi, dipertahankan, atau diganti dengan ajaran Islam. Islam dan tradisi lokal tidak saling meniadakan, tapi justru saling mendukung dengan modifikasi melalui masuknya ajaran-ajaran seperti shalawatan, pengajian agama, doa-doa, bacaan dzikir dan lainnya. ${ }^{32}$ Dengan masuknya nilai-nilai Islam, ruwatan menjadi sesuatu yang baik dan hukumnya bisa naik dari mubah ke sunnah.

Kelima, penerjemahan syarî'ah muthlaqah (ajaran yang bersifat mutlak), berupa ajaran yang tidak disertai petunjuk teknis yang mengikat, ${ }^{33}$ melalui penciptaan tradisi baru. Umat Islam memang diberi ruang untuk melakukan inovasi positif (sunnah hasanah). Bila inovasi itu diikuti oleh orang lain, maka yang merintis mendapat pahalanya. Ajaran Islam mengajarkan untuk melayat kepada orang yang ditinggal mati anggota keluarga. Sebagai orang yang ditimpa musibah, orang lain dianjurkan untuk datang mendoakan, menghibur dan meringankan bebannya. Bentuk meringankan beban itu diterjemahkan dengan membawa beras atau makanan pokok lain bagi yang melayat. Karena dengan itu, ia juga dapat meringankan beban konsumsi para tamu yang melayat. Penerjemahan tersebut menjadi adat yang dapat menjadi hukum memperbolehkan atau menganjurkan orang yang melayat untuk membawa beras dan sejenisnya. Penerjemahan ajaran mutlak dalam kehidupan sehari-hari sehingga menjadi tradisi dapat memperkaya hukum Islam dalam bentuk perilaku yang dapat ditatapkan sebagai sumber hukum.

\section{Penutup}

'Urf dalam bentuk tradisi lokal yang tidak bertentangan langsung dengan nash dapat dipertimbangkan sebagai sumber hukum Islam. Hal ini penting karena tantangan gerakan Islam yang tidak ramah terhadap tradisi lokal dan memaksakan pemahaman tekstual terhadap nash, bahkan penggunaan nash ke persoalan di luar

${ }^{32}$ Muhammad Roy Purwanto, “Akulturasi Islam”..., 35-57.

33Sebagai lawan dari syarî'ah muqayyadah, yaitu ajaran agama yang telah menetapkan petunjuk teknis pelaksanaannya secara mengikat seperti jumlah rakaat shalat, jumlah shalat dalam sehari semalam, nishab dan kadar zakat. 
konteksnya. Sementara keberadaan 'urf sendiri diakui secara oleh nash sebagai dasar hukum dan digunakan oleh para ulama sejak era salaf. Pengetahuan tentang 'urf menjadi syarat mujtahid atau mufti dalam menetapkan hukum dan telah dibahas secara detail klasifikasi, kriteria dan cara penggunaannya.

Hukum Islam (fiqih) sendiri sebagai produk ijtihadi manusiawi tidak lepas dari kehidupan sosial umat manusia sehingga harus mempertimbangkan aspek-aspek kebudayaan, bukan hanya nash. Aspek lainnya yang penting mendapat perhatian adalah melakukan negosiasi antara doktrin dengan tradisi. Upaya ini berfungsi untuk mempertahankan tradisi yang divonis menyimpang dengan memilah unsur-unsurnya antara yang menyimpang dan tidak. Dengan demikian, hukum haram terhadap suatu tradisi, hilang karena tradisinya telah mengalami modifikasi dan berganti dengan tradisi lain yang status hukumnya sudah berubah menjadi mubah atau bahkan sunnah. Upaya penguatan tradisi ini juga penting dilakukan dengan menciptakan tradisi baru dengan menerjemahkan doktrindoktrin yang bersifat mutlak. Dengan munculnya tradisi baru tersebut hukum Islam akan memiliki landasan 'urf yang kaya dan beragam serta sesuai dengan perkemangan kehidupan umat manusia.

\section{Daftar Pusataka}

Asad, Talal, The Idea of an Anthropologi of Islam, Georgetown University, Washington, 1986.

Abû Zayd, Nasr Hâmid, Mafhûm al-Nash, (Beirut: Al-Markaz alTsaqâfî al-'Arabî, 1996)

Henninger, Joseph, "Pre-Islamic Bedouin Religion," dalam Marlyn L. Swartz (ed. \& trans.) Studies on Islam, Oxford University Press, New York, 1981.

Khaldûn, Abd al-Rahmân Ibn, Muqaddimah li Kitâb al-'Ibar wa Dîwân al-Mubtadâ wa al-Khabar fi Ayyâm al-'Arab wa al-'Ajam wa alBarbar wa Man 'Âsharahum min Dzawi al-Shulthân al-Akbar, Dar al-Kutub al-'Ilmiyyah, Beirut, 1992.

Karim, Khalil Abdul, Historisitas Syari'ah Islam, Terj. M. Faisol Fatawi, Pustaka Alief, Yogyakarta, 2003.

Khallaf, Abd al-Wahhab, 'Ilm al-Ushûl al-Figh, Dar al-Qalam, Kairo, 1978. 
Khayyâth, 'Abd al-Azîz al-, Nadzariyyat al-'Urf, Maktab al-Aqsha, Amman, t.t.

Mahasin, Aswab, "Masyarakat Madani dan Lawan-Lawannya: Sebuah Mukadimah" (Kata Pengantar) dalam Ernest Gellner, Membangun Masyarakat Sipil Prasyarat Menuju Kebebasan, Mizan, Bandung, 1995

Mahfudz, M. A. Sahal, Fiqih Sosial: Upaya Pengembangan Madzhab Qauli dan Manhaji, pidato penerimaan Gelar Doktor Honoris Causa Bidang Fiqih Sosial, Universitas Islam Negeri (UIN) Syarif Hidayatullah Jakarta, 2003.

Masood, M. Khalid, Islamic Legal Philosophy, A. Study of Abu Ishaq alShatibi's Life and Thought, International Islamic Publisher, Delhi, 1989.

Mulkhan, Abdul Munir, Islam Murni dan Masyarakat Petani, Bentang Budaya, Yogyakarta, 2000.

----, “Muhammadiyah dan Keragaman BudayaLokal," dalam Zakiyuddin Baidhawy dan Mutohharun Jinan, Agama dan Pluralitas Budaya Lokal, Pusat Studi Budaya dan Perubahan Sosial Universitas Muhammadiyah Surakarta, Surakarta, 2003.

Peters, F.E., Mohammad and the Origin of Islam, State University of New York State, New York, 1995.

Qaradlâwi, Yûsuf al-, Madkhal li Dirâsah al-Syarî'ah al-Islâmiyyah, Maktabah Wahbah, Kairo, 2001.

Qarafî, Syihâb al-Dîn al-, Anwâr al-Burûq fì Anwâ' al-Furûq, Dar alKutub al-'Arabiyyah, Kairo, $1344 \mathrm{H}$.

Schacht, J., Introduction to Islamic Law, Clarendon, Oxford, 1966.

Sunnah, Ahmad Fahmi Abû, Al-'Urf wa al-'Âdat fi Ra'y al-Fuqahâ', Dar al-Fikr al-'Arabi, Mesir, t.t.

Surjo, Joko, dkk., Agama dan Perubahan Sosial; Studi Tentang Hubungan Antara Islam, Masyarakat dan Struktur Sosial-Politik Indonesia, Pusat Studi Antar Universitas-Studi Sosial UGM. Yogyakarta, 1993.

Watt, Montgomery, Muhammad, Prophet and Statesman, Oxford University Press, New York, 1961.

Zarqâ', Mushthafâ, al-Madkhal 'alâ al-Fiqh al-'Âm, Dar al-Fikr, Beirut, 1968.

Zuhayli, Wahbah al-, Ushîl al-Fiqh al-Islâmî, (Damaskus: Dar al-Fikr, 1986) 